fra et miljø i Manchester, Storbritannia, som yter kommunalt baserte tjenester til unge mennesker i krise og som særlig er rettet mot brukere som er sosialt vanskeligstilt eller tilhører etniske minoriteter.

Redaktørene problematiserer i innledningen begrepet kunnskapsbasert praksis, der de fremholder at de behandlingsformene man har kunnskapsgrunnlag om, ofte representerer tiltak med enkle mål og teknikker av relativt kort varighet. Forfatterne vektlegger en tilnærming der praksis, kunnskap og forståelse av fenomener basert på brukernes erfaringer står sentralt mer enn dokumentert effektive behandlingsmetoder.

Det er tre hoveddeler: $\AA$ arbeide sammen med unge mennesker, Misbruk, undertrykkelse og selvskading og Strategier for å overleve.

En ikke-dømmende holdning vektlegges. Dette påpekes som særlig viktig tatt $\mathrm{i}$ betraktning av at mange av pasientene som sliter med selvskading har relasjonstraumer av ulikt slag og strever med utvikling av egen identitet og egenverd. Forståelsen av selvskading som mestringsteknikk for smerte holdes frem, og i forlengelsen av denne forståelsen blir skadereduksjon og utvikling av alternative mestringsmåter viktige elementer i tilnærmingen. Opplæring $i$ aktiv skadebegrensning er kjent fra andre områder, for eksempel utdeling av rene sprøyter til rusmisbrukere, men mindre sentralt som tiltak i forbindelse med selvskading. Andre måter å trene og styrke evnen til å ta ansvar for eget liv og livssituasjon drøftes i relasjon til praktiske intervensjoner som selvhjelpsgrupper og bruk av personlige assistenter i hjemmet i stedet for innleggelse $\mathrm{i}$ institusjon.

Behandling av pasienter med selvskading, ofte tilbakevendende, er en utfordrende oppgave for oss som hjelpere. I fagfeltet har vi erfart at kontrolltiltak ikke er tilstrekkelig. Tvert imot må vi hele tiden gi pasienten så mye ansvar for eget liv og handlinger som hun eller han kan klare.

Boken gir således ikke helt nye perspektiver i forståelse av problematikken eller behandlingsprinsipper. Ved sitt konsekvente fokus i det å spille på lag med pasienten, gi ansvar og myndighet til den som strever med selvskading og de praktiske konsekvensene av denne holdningen, er allikevel boken interessant og utfordrende for folk som arbeider med denne problematikken. Den er imidlertid ikke en grunnleggende lærebok om selvskading, da finnes det bedre norske alternativer.

Tordis Sørensen Høifødt

Universitetssykehuset Nord-Norge

\section{Sykdomsmodellen forklarer ikke selvmordsatferd}

Ellenhorn RD.

\section{Parasuicidality and paradox}

Breaking through the medical model. $199 \mathrm{~s}$, tab, ill. New York, NY: Springer Publishing, 2008. Pris USD 40

ISBN 978-082611546-1

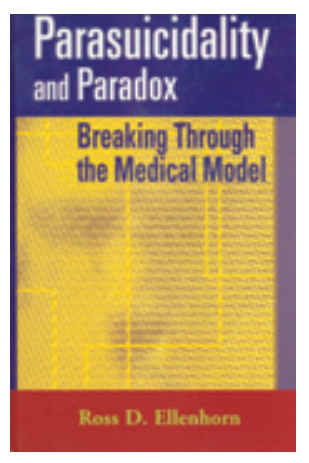

Forfatteren, Ross D. Ellenhorn, er utdannet psykoterapeut, sosialarbeider og sosiolog, med erfaring både som kliniker og leder av ulike psykiatriske avdelinger. Boken er skrevet for alle behandlere av pasienter med suicidale

impulser, spesielt i forhold til problematikken rundt ustabil personlighet (borderline), og den gir detaljerte eksempler på hvordan kommunikasjon mellom behandler og pasient kan virke forsterkende eller dempende på slike impulser.

Et hovedfokus er nettopp hvordan enkelte behandlingssystemer kan forsterke og opprettholde selvmordsimpulser hos pasienter med diagnose ustabil personlighetsforstyrrelse. Pasientene som omtales er definert som tilbakevendende «parasuicidale» - en pasientgruppe som i stor grad reagerer på indre spenning med selvmordstanker eller selvskade. Forfatteren beskriver hvordan trusler om selvskading hos slike pasienter brukes for å få tilgang til behandling i psykisk helsevern, og hvordan pasienter og terapeuter kan vikle seg inn i en type kommunikasjon som ikke fører til personlig vekst og selvstendighet for pasienten, men som tvert imot forsterker selvskadeimpulsene.

For det meste omtales selvmordsimpulser eller -trusler, i mindre grad selvmordsforsøk. Han analyserer slike trusler ut fra et eksistensialfilosofisk og kommunikasjonsteoretisk perspektiv, der kjernen $i$ atferden er angsten for å bli et handlende og selvstendig individ, og målet med suicidaliteten er å sikre seg langsiktig kontakt med behandlingsapparatet. Forfatteren hevder at det har vært lite oppmerksomhet i suicidologien omkring forhold ved behandlingen som opprettholder dette atferdsmønsteret.

Forfatteren har etablert et dagbehandlingsprogram for selvskadere. Behandlingen er sentrert om samspillet mellom person og behandlingsinstitusjon, som for mange av disse pasientene har utviklet en nærmest symbiotisk karakter. Boken er et resultat av erfaring med dette behandlingsprogrammet.
Diagnosen ustabil personlighetsforstyrrelse er sammensatt og lite presis, og forfatteren tviler på at den dekker en spesifikk psykisk sykdom. I stedet viser han hvordan de paradoksene som karakteriserer denne sykdomskategorien egentlig er de paradoksene som karakteriserer den menneskelige eksistens. Det eneste som spesifikt karakteriserer diagnosen er tilstedeværelse av selvmordstrusler eller -atferd, men forfatteren forklarer dette på andre måter enn som symptomer på psykisk lidelse.

I del 2 gis det en rekke eksempler på hvordan ulik teoretisk forståelse av selvskading fører til ulik kommunikasjon mellom pasient og terapeut, med ulikt resultat for pasientene.

Denne boken er ment som en hjelp til terapeuter, som er like mye fanget $i$ institusjonsfeller som pasientene er. Frykten for selvmord blant pasienter styrer mye av terapeuters atferd overfor selvskadere eller de som truer med selvskading, og våre responser er ikke alltid de som bringer pasienter på best måte ut av suicidalitet.

Boken er tankevekkende og anbefales varmt til terapeuter både innenfor og utenfor institusjonsbehandling.

\section{Gudrun Dieserud}

Avdeling for selvmordsforskning og -forebygging

Divisjon for psykisk helse

Nasjonalt folkehelseinstitutt

\section{Selvskading}

\section{Sutton J.}

\section{Healing the hurt within}

Understand self-injury and self-harm, and heal the emotional wounds. 3. utg. 486 s, tab, ill. Oxford: How to Books, 2007. Pris GBP 17 ISBN 978-1-84528-226-4

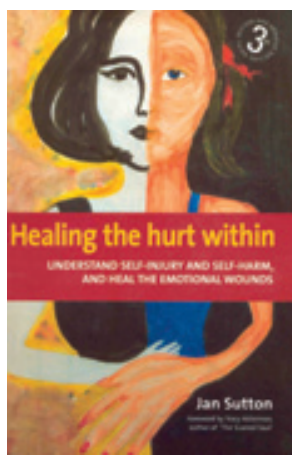

Selvskadende atferd er i ferd med å bli oppdaget som et «nytt» fenomen innenfor ungdomskulturens randsoner. Og selvskading er på få år blitt langt mer synlig i psykiatriske kontekster. For svært mange - foreldre, lærere, hjelpere og behandlere - oppleves slike fenomener som svært utfordrende. De selvpåførte smertene utfordrer våre evner både til å forstå og å handle på virksomme måter.

Det er således åpenbare behov for at leger og andre kan utvikle kompetanse til å møte selvskadingen. $\mathrm{Og}$ nå produseres det tekster $i$ en rekke sjangere, fra vitenskapelige publikasjoner via fagbøker til en rik selvhjelpslit- 